JURNAL Midwifery Update (MU)

http://jurnalmu.poltekkes-mataram.ac.id/index.php/jurnalmu

e-ISSN: 2684-8511 (Online)

\title{
PREVALENSI DAN FAKTOR RISIKO DEPRESI POST PARTUM DI KOTA DENPASAR TAHUN 2019
}

\author{
I Komang Lindayani ${ }^{1}$, Gusti Ayu Marhaeni ${ }^{2}$ \\ ${ }^{1,2}$ Jurusan Kebidanan Politeknik Kesehatan Kemenkes Denpasar
}

\begin{abstract}
Abstrak
Depresi post partum dapat dialami oleh ibu nifas sejak 2 minggu sampai dengan 1 tahun setelah melahirkan. Kondisi ini jika dideteksi sejak awal dan dapat penanganan yang tepat, akan dapat mencegah masalah lebih lanjut. Identifikasi gejala depresi dan faktor risiko terjadinya depresi post partum penting dilakukan. Kuesioner Edinburgh Postpartum Depression Scale $(E P D S)$ sudah sangat umum digunakan di seluruh dunia untuk mendeteksi adanya depresi post partum dengan tingkat sensitivitas sebesar $80 \%$ dan spesifitas $84,4 \%$. Penelitian ini bertujuan untuk menghitung prevalensi kejadian depresi post partum di Kota Denpasar Tahun 2019, mengetahui faktor risiko yang berhubungan dengan kejadian depresi post partu dan menganalisis hubungan antara faktor risiko yang ditemukan. Penelitian ini merupakan jenis penelitian observasional dengan desain cross sectional. Penelitian dilaksanakan di 3 (tiga) puskesmas rawat inap yaitu Puskesmas I Denpasar Timur, IV Denpasar Selatan dan II Denpasar Barat. Responden berjumlah 67 orang. Instrumen yang digunakan adalah kuesioner EPDS, kuesioner faktor yang terkait dengan kehamilan, persalinan dan nifas, dan kuesioner faktor sosial. Analisis univariat dengan menghitung proporsi, analisis bivariat dengan menggunakan uji Chi Square dan analisis multivariate dengan menggunakan regresi logistic. Hasil penelitian menunjukkan prevalensi kejadian depresi post partum sebesar 25,4\%. Faktor risiko yang berhubungan secara bermakna dengan kejadian depresi post partum antara lain : jenis keluarga, nutrisi untuk bayi dan dukungan keluarga. Sedangkan faktor risiko usia, pendidikan, pekerjaan, penghasilan keluarga, paritas, status kehamilan, komplikasi persalinan dan jenis kelamin bayi tidak menunjukkan adanya hubungan yang signifikan. Hasil regresi logistik menunjukkan nutrisi untuk bayi memiliki hubungan yang paling kuat dengan kejadian depresi post partum.
\end{abstract}

Kata kunci : Prevalensi ; faktor risiko ; depresi post partum

PREVELENCE AND RISK FACTOR POST PARTUM DEPRESSION IN DENPASAR 2019

\begin{abstract}
Post partum depression can be experienced by postpartum mothers from 2 weeks to 1 year after giving birth. This condition, if detected early and can be handled properly, will be able to prevent further problems. Identification of depressive symptoms and risk factors for post partum depression is important. The Edinburgh Postpartum Depression Scale (EPDS) questionnaire has been very commonly used worldwide to detect post partum depression with a sensitivity level of $80 \%$ and a specificity of $84.4 \%$. This study aims to calculate the prevalence of post partum depression events in Denpasar City in 2019, determine the risk factors associated with the incidence of post partum depression and analyze the relationship between risk factors found. This research is an observational research with cross sectional design. The study was conducted in 3 (three) inpatient puskesmas, namely Puskesmas I Denpasar Timur, IV Denpasar Selatan and II Denpasar Barat. Respondents numbered 67 people. The instruments used were EPDS questionnaire, factor questionnaire related to pregnancy, childbirth and puerperium, and social
\end{abstract}


factor questionnaire. Univariate analysis by calculating proportions, bivariate analysis using the Chi Square test and multivariate analysis using logistic regression. The results showed the prevalence of post partum depression was $25.4 \%$. Risk factors significantly related to the incidence of post partum depression include: type of family, nutrition for infants and family support. While risk factors for age, education, occupation, family income, parity, pregnancy status, complications of childbirth and sex of the baby did not show a significant relationship. Logistic regression results show that nutrition for infants has the strongest association with the incidence of post partum depression.

Keywords: prevalence; risk factors ; post partum depression

\section{Pendahuluan}

Kelahiran seorang anak merupakan suatu peristiwa penting dalam kehidupan seorang perempuan. Kejadian ini akan mempengaruhi berbagai aspek dalam hidupnya termasuk persepsi terhadap diri, peran sosial dan hubungan interpersonal. ${ }^{1}$ Meskipun pengalaman ini dianggap sebagai suatu hal yang lazim dialami, namun ibu post partum memerlukan adaptasi baik fisik, psikologis maupun sosial yang pada sebagian ibu tidak mudah untuk dilakukan. ${ }^{2}$

Masa nifas dimulai sejak 1 jam setelah lahirnya plasenta sampai dengan 6 minggu (42 hari) setelah itu. Gangguan suasana hati (mood disorder) merupakan masalah umum yang terjadi selama periode masa nifas. Ada 3 jenis gangguan yang dapat terjadi pada periode ini antara lain : baby blues, depresi post partum dan psikosis post partum. Baby blues melanda hampir 80\% ibu, gangguan ini lebih ringan dibandingkan depresi post partum biasanya muncul mulai hari ke-2 sampai dengan 2 minggu post partum dan akan hilang dengan sendirinya. Gejala umum dari baby blues ini antara lain : rasa khawatir, kurang percaya diri, menangis tanpa sebab yang jelas, sensitif, mudah marah dan gelisah. Apabila baby blues ini menetap maka 10-15\% menjadi depresi post partum yang biasanya muncul sejak 2 minggu sampai 1 tahun post partum dengan gejala : adanya episode depresi, ketakutan irasional terkait kesehatannya dan bayinya dan bahkan sampai ada keinginan untuk bunuh diri maupun membunuh bayinya. ${ }^{2}$ Psikosis sudah dikategorikan sebagai gangguan mental berat.

Data dari Center of Diseases Control dari tahun 2004 - 2012, kejadian depresi post partum sebesar $11,5 \%$ dari 27 negara. ${ }^{3}$ Prevalensi depresi post partum di Asia cukup tinggi dan bervariasi yaitu sekitar 3,5\% sampai dengan 63,3\%. ${ }^{4}$ Prevalensi di negara berkembang adalah sekitar 1,9\% sampai dengan $82,1 \%$, sedangkan di negara maju kejadiannya sekitar 5,2\% sampai dengan 74\%. ${ }^{5}$ Prevalensi depresi post partum di Asia Tenggara sebesar 27\% dimana prevalensi di Indonesia sebesar 3,7\%. Angka ini sedikit lebih rendah dibandingkan prevalensi di India yaitu 4,5\%. ${ }^{6}$ Studi nasional di Indonesia yang dilakukan bersamaan dengan Riset Kesehatan Dasar tahun 2010 didapatkan bahwa prevalensi depresi 20 post partum sebesar 2,32\% (440/18937) dimana risiko akan meningkat apabila ibu melahirkan bayi dengan berat lahir rendah dan sangat rendah, mengalami komplikasi pasca persalinan dan mengalami persalinan macet. Penelitian yang dilakukan di Puskesmas Morokembangan Surabaya, menunjukkan bahwa sebesar 53\% ibu nifas mengalami depresi post partum ringan. ${ }^{7}$ Studi lain yang dilakukan di Kabupaten Sukoharjo Jawa Tengah menemukan prevalensi sebesar 18,5\% 
dimana risiko akan meningkat secara signifikan apabila terdapat komplikasi persalinan, kehamilan yang tidak diinginkan dan penghasilan keluarga yang rendah, sedangkan risiko akan menurun dipengaruhi oleh usia, self eficacy yang lebih kuat, perbaikan strategi coping. ${ }^{8}$ Studi yang sama yang dilakukan di Lombok Timur, Nusa Tenggara Barat didapatkan prevalensi yang lebih tinggi yaitu sebesar 39,5\% dan dukungan keluarga berpengaruh secara signifikan terhadap kejadian depresi post partum. ${ }^{9}$ Sampai saat ini Propinsi Bali belum memiliki data kejadian depresi post partum secara pasti, namun pada tahun 2016 Dira dan Wahyuni melakukan penelitian di Kota Denpasar Bali untuk menemukan prevalensi depresi post partum dengan menggunakan instrumen skrining Edinburgh Postnatal Depression Scale (EPDS), hasil penelitian menunjukkan bahwa 20,5\% dari 44 responden mengalami depresi post partum, dimana faktor risiko yang berpengaruh terhadap terjadinya depresi post partum adalah riwayat pendidikan ibu yang rendah, primipara, umur, riwayat anak meninggal dan kehamilan yang tidak diinginkan. ${ }^{10}$

Ibu yang mengalami depresi tidak mampu mengasuh bayinya dengan baik, jika masalah ini berlanjut maka akan menyebabkan dampak negatif jangka panjang terhadap perkembangan kognitif, emosional, sosial dan perilaku anak. ${ }^{11}$ Jadi akibat depresi post partum ini tidak hanya berdampak pada penderita namun akan berdampak pula pada bayi dan keluarga secara keseluruhan. Untuk itu sangat penting untuk melakukan deteksi dini dan penanganan yang tepat untuk menurunkan prevalensi dari masalah ini. Kuesioner Edinburgh Postpartum Depression Scale (EPDS) digunakan secara luas di dunia sebagai alat untuk mendeteksi gejala depresi post partum. Kuesioner ini memiliki sensitifitas $80 \%$ dan spesifitas $84,4 \%{ }^{12}$ Hal ini menunjukkan instrument ini sangat baik digunakan untuk mendeteksi suatu gejala. Penelitian yang dilakukan oleh Dira dan Wahyuni (2016) di Kota Denpasar Bali, mencari karakteristik ibu yang berpengaruh terhadap kejadian depresi post partum. Karakteristik tersebut antara lain : umur, pekerjaan, pendidikan terakhir, paritas serta jumlah anak yang hidup dan meninggal. Hasil penelitian menunjukkan bahwa faktor risiko yang berpengaruh terhadap terjadinya depresi post partum adalah riwayat pendidikan ibu yang rendah, primipara, umur, riwayat anak meninggal dan kehamilan yang tidak diinginkan. Namun hasil yang didapatkan belum dianalisis lebih lanjut untuk mengetahui variabel mana yang berpengaruh secara langsung terhadap kejadian depresi post partum. Penelitian yang dilakukan oleh Adama, et.al. (2015) di Yaounde, Kamerun, menunjukkan faktor risiko yang terbukti berpengaruh terhadap kejadian depresi post partum antara lain : ketidakpuasan terhadap kehidupan pernikahan, adanya masalah keuangan, konflik dengan pasangan, baby blues, masalah menyusui dan gangguan tidur bayi. Sedangkan studi yang dilakukan Mathisen, et.al. (2013) di Argentina mendapatkan bahwa faktor yang berhubungan terhadap kejadian depresi post partum antara lain menyusui yang tidak eksklusif, persalinan melalui SC, adanya komplikasi perinatal dan multiparitas.

Banyak faktor risiko yang berpengaruh terhadap terjadinya depresi post partum yang belum di teliti di Wilayah Kota Denpasar. Untuk itu peneliti tertarik untuk mengetahui prevalensi dan faktor risiko yang berpengaruh terhadap kejadian depresi post partum di Kota Denpasar. 


\section{Metode}

Penelitian merupakan jenis observasional dengan rancangan potong lintang (Cross Sectional) untuk mengetahui faktor risiko yang berhubungan dengan kejadian depresi post partum pada ibu nifas 3 hari-6 minggu yang bertempat tinggal di Kota Denpasar. Penelitian dilaksanakan di Kota Denpasar di wilayah kerja puskesmas rawat inap di Kota Denpasar antara lain Puskesmas IV Denpasar Selatan, Puskesmas I Denpasar Timur dan Puskesmas Pembantu Dauh Puri (Puskesmas II Denpasar Barat). Penelitian dilaksanakan pada bulan Juli - September 2019.

Pengambilan besar sampel menggunakan teknik proportional sampling untuk menentukan jumlah responden di masing - masing puskesmas. Lalu untuk menentukan responden akan dilakukan dengan menggunakan metode purposive sampling dimana kriteria responden sudah ditentukan oleh peneliti. Besar sampel ditentukan dengan menggunakan rumus besar sampel menurut Slovin. Didapatkan besar sampel 61 ditambah $10 \%$ jadi besar sampel minimal adalah 67 responden.

Pengukuran kejadian depresi post partum akan diukur dengan menggunakan kuesioner yang sudah baku yang dikembangkan oleh Cox, et.al. yaitu Edinburgh Postnatal Depression Scale (EPDS). Kuesioner ini terdiri dari 10 pertanyaan, masing masing pertanyaan memiliki 4 respon dengan skala Likert dari $0-3$. Nilai maksimal 30, dan terendah adalah 0 . Disebut mengalami depresi apabila skor $\geq 10$. EPDS memiliki sensitifitas sebesar $80 \%$ dan spesifitas $84,4 \%$ (Santos, et.al., 2007). Sedangkan EPDS dalam bahasa Indonesia memiliki sensitifitas sebesar $86 \%$ dan spesifitas $78 \%$ (Nasri, 2017). Pengukuran faktor yang terkait dengan kehamilan, persalinan dan nifas yakni : paritas, status kehamilan, komplikasi persalinan, jenis kelamin bayi, dan nutrisi bayi dengan menggunakan kuesioner. Pengukuran faktor sosial yaitu dukungan keluarga dengan menggunakan kuesioner.

Prevalensi depresi post partum, faktor yang berkaitan dengan kehamilan, persalinan dan nifas serta data faktor sosial diukur dengan cara menghitung rata-rata lalu akan dihitung proporsinya (\%). Untuk mengetahui hubungan antar variabel independen dengan variabel dependen dilakukan analisis dengan menggunakan uji Chi Square. Variabel independen dengan $\mathrm{P}$ Value $<0,25$ dilakukan kembali analisis dengan menggunakan uji regresi logistik untuk mengontrol variabel confounding dan untuk menentukan faktor prediktor dari kejadian depresi post partum. P-value $<0,05$ digunakan sebagai kriteria signifikansi dan OR dengan tingkat kepercayaan 95\% sebagai indikator kekuatan hubungan.

\section{Hasil Penelitian dan Pembahasan}

Tabel 1. Data Faktor Yang Terkait dengan Kehamilan, Persalinan dan Nifas

\begin{tabular}{lcc}
\hline \multicolumn{1}{c}{ Variabel } & Frekuensi $(\mathbf{n}=\mathbf{6 7})$ & Persentase (\%) \\
\hline Paritas & & \\
- Primipara & 24 & 35,8 \\
- Multipara & 43 & 64,2 \\
\hline Status Kehamilan & & \\
- Diinginkan & 66 & 98,5 \\
\hline
\end{tabular}




\begin{tabular}{lcc}
\hline - Tidak diinginkan & 1 & 1,5 \\
\hline Komplikasi saat persalinan & & \\
- Tidak ada & 64 & 95,5 \\
- Ada & 3 & 4,5 \\
\hline Jenis kelamin bayi & & \\
- Sesuai & 65 & 97 \\
- Tidak sesuai & 2 & 3 \\
\hline Nutrisi bayi & & \\
- ASI & 37 & 55,2 \\
- ASI + susu formula & 30 & 44,8
\end{tabular}

Tabel 1 di atas menunjukkan faktor - faktor yang berkaitan dengan kehamilan, persalinan dan nifas. Sebagian responden merupakan multipara yaitu sebanyak 43 orang (64,2\%). Hampir semua menginginkan kelahiran anak terakhir yaitu sebanyak 66 orang (98,5\%). Hampir semua responden tidak mengalami komplikasi saat persalinan terakhir yaitu sebanyak 64 orang $(95,5 \%)$, hampir semua jenis kelamin anak terakhir sesuai dengan harapan yaitu sebanyak 65 orang $(97 \%)$ dan sebagian besar hanya memberikan ASI untuk bayinya yaitu sebanyak 37 orang (55,2\%).

Tabel 2. Data Dukungan Keluarga

\begin{tabular}{lcc}
\hline \multicolumn{1}{r}{ Variabel } & Frekuensi $(\mathbf{n}=\mathbf{6 7})$ & Persentase (\%) \\
\hline Dukungan keluarga & & \\
- Baik & 61 & 91 \\
- Kurang & 6 & 9 \\
\hline
\end{tabular}

Tabel 2 di atas menunjukkan bahwa sebagian besar responden mendapatkan dukungan yang baik dari keluarganya yaitu sebanyak 61 orang (91\%).

Tabel 3. Data Jenis Keluarga Responden

\begin{tabular}{lcc}
\hline \multicolumn{1}{c}{ Variabel } & Frekuensi $(\mathbf{n}=\mathbf{6 7})$ & Persentase $\mathbf{~ \% )}$ \\
\hline Jenis Keluarga & & \\
- Inti & 26 & 38,8 \\
- Besar & 41 & 61,2 \\
\hline
\end{tabular}

Tabel 3 di atas menunjukkan bahwa sebagian besar responden tinggal bersama keluarga besar yaitu sebanyak 41 orang $(61,2 \%)$.

Tabel 4. Data Kejadian Gejala Depresi Post Partum pada Responden

\begin{tabular}{lcc}
\hline \multicolumn{1}{c}{ Variabel } & Frekuensi $(\mathbf{n}=\mathbf{6 7})$ & Persentase \\
\hline Gejala & & \\
- Tidak depresi & & 74,6 \\
- Depresi & 50 & 25,4 \\
\hline
\end{tabular}

Tabel 4 di atas menunjukkan bahwa prevalensi gejala Depresi Post Partum dalam penelitian ini adalah sebesar $25,4 \%$.

Tabel 5. Distribusi Hubungan antara Paritas dengan Kejadian Gejala Depresi Post Partum

\begin{tabular}{cccccccc}
\hline \multirow{2}{*}{ Paritas } & \multicolumn{3}{c}{ Kejadian Depresi } & \multicolumn{3}{c}{ Potalue } \\
\cline { 2 - 6 } & \multicolumn{2}{c}{ Tidak Depresi } & \multicolumn{2}{c}{ Depresi } & \multicolumn{3}{c}{ Total } \\
\hline & N & \% & n & \% & n & \% & \\
\hline Primipara & 17 & 70,8 & 7 & 29,2 & 24 & 100 & 0,594 \\
Multipara & 33 & 76,7 & 10 & 23,3 & 43 & 100 & \\
\hline Jumlah & 50 & 74,6 & 17 & 25,4 & 67 & 100 & \\
\hline
\end{tabular}

Tabel 5 di atas menunjukkan bahwa sebanyak 7 orang $(29,2 \%)$ dari kelompok responden primipara dan sebanyak 10 orang $(23,3 \%)$ dari kelompok responden 
multipara yang kemungkinan mengalami gejala depresi post partum. Hasil analisis menunjukkan nilai P-value sebesar 0,594 $(\alpha>0,05)$ sehingga tidak terdapat hubungan yang signifikan antara paritas responden dengan kejadian gejala depresi post partum.

Tabel 6. Distribusi Hubungan antara Status Kehamilan dengan Kejadian Gejala Depresi Post Partum

\begin{tabular}{|c|c|c|c|c|c|c|c|}
\hline \multirow{3}{*}{$\begin{array}{c}\text { Status } \\
\text { Kehamilan } \\
\end{array}$} & \multicolumn{4}{|c|}{ Kejadian Depresi } & \multirow{2}{*}{\multicolumn{2}{|c|}{ Total }} & \multirow[t]{3}{*}{$P$-value } \\
\hline & \multicolumn{2}{|c|}{ Tidak Depresi } & \multicolumn{2}{|c|}{ Depresi } & & & \\
\hline & $\mathbf{N}$ & $\%$ & n & $\%$ & $\mathbf{n}$ & $\%$ & \\
\hline Diinginkan & 50 & 75,8 & 16 & 25 & 66 & 100 & 0,084 \\
\hline Tidak Diinginkan & 0 & 0 & 1 & 33,3 & 1 & 100 & \\
\hline Jumlah & 50 & 74,6 & 17 & 25,4 & 67 & 100 & \\
\hline
\end{tabular}

Tabel 6 di atas menunjukkan bahwa sebanyak 16 orang (25\%) dari kelompok responden dengan status kehamilan diinginkan dan sebanyak 1 orang $(33,3 \%)$ dari kelompok responden dengan status kehamilan tidak diinginkan yang kemungkinan mengalami gejala depresi post partum. Hasil analisis menunjukkan nilai P-value sebesar $0,084(\alpha>0,05)$ sehingga tidak terdapat hubungan yang signifikan antara status kehamilan dengan kejadian gejala depresi post partum.

Tabel 7. Distribusi Hubungan antara Komplikasi Saat Persalinan dengan Kejadian Gejala Depresi Post Partum

\begin{tabular}{cccccccc}
\hline \multirow{2}{*}{$\begin{array}{c}\text { Komplikasi } \\
\text { Persalinan }\end{array}$} & \multicolumn{3}{c}{ Tejadian Depresi } & \multicolumn{3}{c}{ Total } & \multirow{2}{*}{ P-value } \\
\cline { 2 - 6 } & $\mathbf{n}$ & $\mathbf{\%}$ & $\mathbf{n}$ & $\mathbf{\%}$ & $\mathbf{n}$ & $\mathbf{\%}$ & \\
\hline Tidak ada & 48 & 75 & 16 & 25 & 64 & 100 & 0,746 \\
Ada & 2 & 66,7 & 1 & 33,3 & 3 & 100 & \\
\hline Jumlah & 50 & 74,6 & 17 & 25,4 & 67 & 100 & \\
\hline
\end{tabular}

Tabel 7 di atas menunjukkan bahwa sebanyak 16 orang (25\%) dari kelompok responden yang tidak mengalami komplikasi saat persalinan dan sebanyak 1 orang $(33,3 \%)$ dari kelompok responden yang mengalami komplikasi saat persalinan yang kemungkinan mengalami gejala depresi post partum. Hasil analisis menunjukkan nilai P-value sebesar 0,746 $(\alpha>0,05)$ sehingga tidak terdapat hubungan yang signifikan antara komplikasi persalinan dengan kejadian gejala depresi post partum.

Tabel 8. Distribusi Hubungan antara Jenis Kelamin Bayi dengan Kejadian Gejala Depresi Post Partum

\begin{tabular}{cccccccc}
\hline \multirow{2}{*}{$\begin{array}{c}\text { Jenis Kelamin } \\
\text { Bayi }\end{array}$} & \multicolumn{3}{c}{ Tidak Depresi } & \multicolumn{2}{c}{ Depresi } & \multicolumn{3}{c}{ Total } & \multirow{2}{*}{ P-value } \\
\cline { 2 - 6 } & n & \% & n & \% & n & \% & \\
\hline Sesuai & 49 & 75,4 & 16 & 24,6 & 26 & 100 & 0,416 \\
Tidak sesuai & 1 & 50 & 1 & 50 & 41 & 100 & \\
\hline Jumlah & 50 & 74,6 & 17 & 25,4 & 67 & 100 & \\
\hline
\end{tabular}

Tabel 8 di atas menunjukkan bahwa sebanyak 16 orang $(24,6 \%)$ dari kelompok responden dimana jenis kelamin anak sesuai harapan dan sebanyak 1 orang $(50 \%)$ dari kelompok responden dimana jenis kelamin anak tidak sesuai dengan harapan yang kemungkinan mengalami gejala depresi post partum. Hasil analisis menunjukkan nilai P-value sebesar 0,416 $(\alpha>0,05)$ sehingga tidak terdapat hubungan yang signifikan antara jenis kelamin anak dengan kejadian gejala depresi post partum. 
Tabel 9. Distribusi Hubungan antara Nutrisi Bayi dengan Kejadian Gejala Depresi Post Partum

\begin{tabular}{|c|c|c|c|c|c|c|c|}
\hline \multirow{3}{*}{$\begin{array}{c}\text { Nutrisi } \\
\text { Bayi }\end{array}$} & \multicolumn{4}{|c|}{ Kejadian Depresi } & & & \multirow[t]{3}{*}{ P-value } \\
\hline & \multicolumn{2}{|c|}{ Tidak Depresi } & \multicolumn{2}{|c|}{ Depresi } & \multicolumn{2}{|c|}{ Total } & \\
\hline & $\mathbf{n}$ & $\%$ & $\mathbf{n}$ & $\%$ & $\mathbf{n}$ & $\%$ & \\
\hline ASI & 34 & 91,9 & 3 & 8,1 & 37 & 100 & 0,001 \\
\hline ASI + Sufor & 16 & 55,2 & 14 & 44,8 & 29 & 100 & \\
\hline Jumlah & 50 & 74,6 & 17 & 25,4 & 67 & 100 & \\
\hline
\end{tabular}

Tabel 9 di atas menunjukkan bahwa sebanyak 3 orang $(8,1 \%)$ dari kelompok responden yang memberikan ASI saja untuk bayinya dan sebanyak 14 orang $(44,8 \%)$ dari kelompok responden yang memberikan ASI dan susu formula untuk bayinya yang kemungkinan mengalami gejala depresi post partum. Hasil analisis menunjukkan nilai P-value sebesar $0,001(\alpha<0,05)$ sehingga terdapat hubungan yang signifikan antara nutrisi bayi dengan kejadian gejala depresi post partum.

Tabel 10. Distribusi Hubungan antara Dukungan Keluarga dengan Gejala Kejadian Depresi Post Partum

\begin{tabular}{cccccccc}
\hline \multirow{2}{*}{$\begin{array}{c}\text { Dukungan } \\
\text { Keluarga }\end{array}$} & \multicolumn{3}{c}{ Tejadian Depresi } & \multicolumn{2}{c}{ P-value } \\
\cline { 2 - 6 } & $\mathbf{n}$ & $\mathbf{\%}$ & $\mathbf{n}$ & $\mathbf{\%}$ & $\mathbf{n}$ & $\mathbf{\%}$ & \multicolumn{2}{c}{ Total } \\
\hline Baik & 50 & 82 & 11 & 18 & 61 & 100 & 0,000 \\
Kurang & 0 & 0 & 6 & 100 & 6 & 100 & \\
\hline Jumlah & 50 & 74,6 & 17 & 25,4 & 67 & 100 \\
\hline
\end{tabular}

Tabel 10 di atas menunjukkan bahwa sebanyak 11 orang (18\%) dari kelompok responden dengan dukungan keluarga baik dan sebanyak 6 orang (100\%) dari kelompok responden dengan dukungan keluarga kurang yang kemungkinan mengalami gejala depresi post partum. Hasil analisis menunjukkan nilai P-value sebesar 0,000 $(\alpha<0,05)$ sehingga terdapat hubungan yang signifikan antara dukungan keluarga dengan kejadian gejala depresi post partum.

Tabel 11. Distribusi Hubungan antara Jenis Keluarga dengan Kejadian Gejala Depresi Post Partum

\begin{tabular}{|c|c|c|c|c|c|c|c|}
\hline \multirow{3}{*}{$\begin{array}{c}\text { Jenis } \\
\text { Keluarga } \\
\end{array}$} & \multicolumn{4}{|c|}{ Kejadian Depresi } & & & \multirow[t]{3}{*}{ P-value } \\
\hline & \multicolumn{2}{|c|}{ Tidak Depresi } & \multicolumn{2}{|c|}{ Depresi } & \multicolumn{2}{|c|}{ Total } & \\
\hline & $\mathbf{n}$ & $\%$ & $\mathbf{n}$ & $\%$ & $\mathbf{n}$ & $\%$ & \\
\hline Inti & 25 & 96,2 & 1 & 3,8 & 26 & 100 & 0,001 \\
\hline Besar & 25 & 61,0 & 16 & 39 & 41 & 100 & \\
\hline Jumlah & 50 & 74,6 & 17 & 25,4 & 67 & 100 & \\
\hline
\end{tabular}

keluarga inti, sebanyak 1 orang $(3,8 \%)$ yang kemungkinan mengalami gejala depresi post partum, sedangkan pada kelompok responden jenis keluarga besar sebanyak 16 orang (39\%) kemungkinan mengalami gejala depresi post partum. Hasil analisis menunjukkan nilai P-value sebesar $0,001(\alpha<0,05)$ sehingga terdapat hubungan yang signifikan antara jenis keluarga dengan kejadian gejala depresi post partum. Variabel variable yang berhubungan dengan kejadian gejala depresi post partum meliputi : jenis keluarga, nutrisi bayi dan dukungan keluarga dilakukan analisis multivariat dengan menggunakan regresi logistik dengan batas kemaknaan $p<0,05$. Hasil analisis ditunjukkan pada tabel di bawah ini. 
Tabel 12. Hasil Uji Regresi Logistik antara Jenis Keluarga, Nutrisi bayi dan Dukungan Keluarga yang Berhubungan dengan Kejadian Gejala Depresi Post Partum

\begin{tabular}{cccc}
\hline Variabel & OR & $\mathbf{9 5 \%}$ CI & P-value \\
\hline Jenis keluarga & 0,098 & $0,010-0,921$ & 0,042 \\
Nutrisi bayi & 0,046 & $0,005-0,417$ & 0,006 \\
Dukungan keluarga & 0,000 & $0,000-0,000$ & 0,999 \\
\hline
\end{tabular}

Tabel 12 di atas menunjukkan bahwa faktor risiko yang berhubungan dengan kejadian gejala depresi post partum adalah jenis keluarga ( $p$-value $=0,042)$ dan nutrisi bayi ( $\mathrm{p}$-value $=0,006)$. Kekuatan hubungan faktor risiko jenis keluarga $(\mathrm{OR}=0,098)$ lebih besar dibandingkan dengan $\mathrm{OR}$ nutrisi bayi $(\mathrm{OR}=0,046)$. Hasil penelitian ini menunjukkan bahwa prevalensi ibu nifas yang kemungkinan mengalami depresi post partum adalah sebesar 25,4\% sedikit lebih tinggi dibandingkan dengan penelitian sebelumnya. Kelompok responden dengan jenis keluarga inti mengalami gejala depresi post partum sebanyak 3,8 \% sedangkan kelompok dari keluarga besar sebanyak 39\%. Hal ini menunjukkan bahwa responden yang hidup dalam kondisi keluarga besar mengalami kecenderungan mengalami depresi post partum. Penelitian ini membuktikan bahwa jenis keluarga memiliki hubungan yang signifikan ( $p$-value $=0,001)$ dengan kejadian depresi post partum dimana struktur keluarga yang besar memiliki kemungkinan yang lebih besar untuk mengalami depresi.

Hasil penelitian ini tidak sejalan dengan penelitian yang dilakukan oleh Cankorur, et.al. (2014) di Turki, dimana struktur keluarga tidak berhubungan secara signifikan dengan kejadian depresi post partum. ${ }^{13}$ Hal ini mungkin disebabkan oleh karena perbedaan budaya antara di Negara Turki dengan di Indonesia khususnya di Bali. Bali menganut budaya patriarki dimana lelaki menjadi otoritas yang sentral dalam segala bentuk organisasi sosial termasuk keluarga. Termasuk seringnya perempuan Bali yang mendeskriditkan perempuan lain. Jadi hal ini mungkin yang menjadi penyebab meningkatnya kejadian depresi post partum pada responden yang tinggal bersama dengan anggota keluarga lain selain suami dan anaknya.

Kelompok responden yang memberikan ASI dan susu formula sebanyak 44,8\% mengalami gejala depresi post partum, sedangkan kelompok responden yang memberikan ASI saja hanya $8,1 \%$ yang mengalami gejalanya. Penelitian ini membuktikan bahwa nutrisi yang diberikan untuk bayi berhubungan secara bermakna ( $p$-value $=0,000)$ dengan kejadian depresi post partum. Hal ini sejalan dengan penelitian Mezzacappa and Katkin (2002) yang menyatakan bahwa ibu yang memberikan susu formula dapat menurunkan mood yang positif dari ibu. Menyusui dapat memberikan efek perbaikan baik dalam jangka pendek maupun panjang pada depresi post partum. ${ }^{14}$

Kelompok responden yang mendapatkan dukungan keluarga yang kurang sebanyak 100\% menunjukkan gejala depresi post partum. Sedangkan kelompok yang mendapat dukungan keluarga yang baik, hanya sebesar 18\% yang mengalami gejalanya. Hasil penelitian ini menunjukkan bahwa terdapat hubungan yang signifikan ( $p$-value $=$ $0,00)$ antara dukungan keluarga dengan kejadian gejala depresi post partum. Responden yang mendapatkan dukungan yang baik dari keluarganya cenderung memiliki 
kemungkinan mengalami depresi post partum lebih rendah dibandingkan dengan yang dukungan yang kurang. Dalam penelitian ini semua responden yang mendapat dukungan yang kurang mengalami gejala depresi post partum. Wanita yang mendapat dukungan yang baik akan merasa dihargai, diperhatikan dan dicintai oleh keluarganya sebaliknya yang mendapat dukungan yang kurang mengakibatkan wanita menjadi lebih sensitif dan cenderung mengalami depresi.

Dukungan merupakan suatu prediktor individu yang paling kuat dan konsisten untuk penyesuaian individu. ${ }^{15}$ Analisis multivariat yang dilakukan dengan uji regresi logistik menunjukkan bahwa jenis keluarga ( $\mathrm{OR}=0,098)$ memiliki hubungan paling kuat dengan kejadian depresi post partum dibandingkan dengan faktor risiko nutrisi untuk bayi ( $\mathrm{OR}=0,046)$. Hal ini mungkin sangat erat hubungannya dengan budaya setempat khususnya di Bali yang menganut sistem patrilineal / purusa. Hal ini membutuhkan penelitian lebih lanjut untuk mengetahui penyebabnya. Terkait dengan adanya hubungan yang bermakna antara nutrisi untuk bayi dengan kejadian depresi post partum kemungkinan hal tersebut terjadi karena ibu yang memutuskan untuk memberikan susu formula pada bayinya biasanya memiliki kesulitan dalam menyusui seperti lecet pada puting susu, ASI dirasakan tidak mencukupi kebutuhan bayi, persiapan ditinggal bekerja, self efficacy yang rendah, dll.

Program kunjungan nifas pada ibu nifas sudah dijalankan oleh puskesmas di Kota Denpasar sebagai upaya pemeliharaan kesehatan pada ibu pasca melahirkan dan bayi baru lahir. Pada program tersebut salah satu yang dipantau adalah kondisi psikologis ibu. Namun belum dilakukan skrining depresi post partum pada ibu nifas menggunakan kuesioner. Mungkin berdasarkan hasil penelitian ini dapat dijadikan sebagai pertimbangan bagi pemegang kebijakan untuk rutin melakukan skrining dengan menggunakan kuesioner EPDS ini untuk dapat menjaring ibu nifas yang menunjukkan gejala awal depresi post partum.

Penelitian ini memiliki beberapa kelemahan yang mungkin dapat diperbaiki pada penelitian selanjutnya. Keterbatasan tersebut antara lain : jumlah sampel yang digunakan kurang besar dengan banyaknya variabel yang ingin dibuktikan. Selain itu akan lebih baik apabila penelitian ini dilanjutkan dengan penelitian dengan desain case control.

\section{Kesimpulan}

1. Prevalensi kejadian gejala Depresi Post Partum di Kota Denpasar Tahun 2019 adalah sebesar $25,4 \%$

2. Faktor risiko yang berhubungan dengan kejadian Gejala Depresi Post Partum adalah jenis keluarga, nutrisi untuk bayi dan dukungan keluarga.

3. Faktor risiko yang paling kuat berhubungan dengan kejadian gejala depresi post partum adalah jenis keluarga dan nutrisi untuk bayi. 


\section{Daftar pustaka}

1. Evagorou, O., Arvaniti, A., Samakouri, M., 2016. Cross Cultural Approach of Postpartum Depression : Manifestasion, Practices Applied, Risk Factors and Therapiutic Interventions. Psychiatr Q. 87 : 129-154

2. Habel, C., Feeley N., Hayton, B., Bell L., Zelkowitz P., 2015. Causes of Women's Postpartum Depression Symptoms : Men's and Women's Perceptions. Midwifery. $31(7): 728-734$

3. Rockhill KM, Ko JY, Tong VT, Morrow B, Far SL., 2017. Trends in Postpartum Depressive Symptoms - 27 States 2004, 2008, and 2012. MMWR : Morbidity \& Mortality Weekly Report. 66(6) : $153-158$

4. Yusuf ASM., Tang L, Binns CW, Lee AH., 2015. Prevalence and Risk Faktors For Postnatal Depression in Sabah, Malaysia. Women and Birth. 28(1) : 25-29

5. Tikmani SS., Soomro T, Tikmani P, 2016. Prevalence and Determinants of Postpartum Depression in a Tertiary Care Hospital. Austin J Obstetri Gynecol. 3(2) $: 0-4$

6. WHO, 2013. Maternal Mental Health. Available at www.who.int/mental_health/maternal-child/maternal_mental_health/en

7. Indriasari, S., 2017. Tingkat Depresi pada Ibu Postpartum di Puskesmas Morokrembangan Surabaya. Dunia Keperawatan. 5(1): 43-49

8. Putriarsih, R., Budihastuti, U.R., Murti, B., 2018. Prevalence and Determinant of Postpartum Depression in Sukoharjo District, Central Java. Journal of Maternal and Child Health. 3 (1) : 11-24

9. Nasri, N., Wibowo, A., Ghozali, E.W., 2017. Faktor Determinan Depresi Post Partum di Kabupaten Lombok Timur. Buletin Penelitian Sistem Kesehatan. 20 : 8995

10. Dira, IKPA., Wahyuni, AAS. 2016. Prevalensi dan Faktor Risiko Depresi Post Partum di Kota Denpasar Menggunakan Edinburgh Postpartum Depression Scale (EPDS). E-Jurnal Medika.5(7).

11. Mathisen, SE., Glavin, K., Lien, L., Lagerlov, P., 2013. Prevalence and Risk Factor for Postpartum Depressive Symptoms in Argentina : A Cross-sectional Study. International Journal of Women's Health. $5: 787-793$

12. Santos, IS., et.al., 2007. Validation of The Edinburgh Postnatal, Depression Scale (EPDS) in a sample of mother from the 2004 Pelotas Birth Cohort Study. Cadernos de Saude Publica. 23 : 385-96

13. Cankorur, VS., Abas, M., Berksun, O., Stewart, R., 2014. Social Support And The Incidence And Persistence Of Depression Between Antenatal And Postnatal Examinations In Turkey: A Cohort Study. BMJ Open : Vol 5 Issue 4. Available at : http://dx.doi.org/10.1136/bmjopen-2014-006456

14. Mezzacappa, ES., Katlin, ES. 2002. Breast-feeding is associated with reduced perceived stress and negative mood in mothers. Health Psychol. 2002 Mar; 21(2):187-93.

15. Reid KM, Taylor MG (2015). Social Support, Stress, and Maternal Postpartum Depression: A Comparison of Supportive Relationships, Social Science Research. Elsevier Inc., 54: 246-262. doi: 10.1016/j.ssresearch.2015.08.009. 